\title{
PSYCHOLOGICAL EMPOWERMENT, JOB INSECURITY AND EMPLOYEE ENGAGEMENT
}

\section{Authors:}

Marius W. Stander

Sebastiaan Rothmann ${ }^{1,2}$

\section{Affiliations:}

${ }^{1}$ School of Behavioural

Sciences, North-West

University, South Africa

${ }^{2}$ Department of Human

Sciences, University of

Namibia, Namibia

\section{Correspondence to:}

Sebastiaan Rothmann

email:

ian@ianrothmann.com

Postal address:

PO Box 11789, Klein

Windhoek, Namibia 9000

\section{Keywords:}

engagement; insecurity; well-being; empowerment; affective job insecurity

\section{Dates:}

Received: 06 Aug. 2009

Accepted: 10 Nov. 2009

Published: 28 May 2010

How to cite this article:

Stander, M.W.,

\& Rothmann, $\mathrm{S}$

(2010). Psychological empowerment, job insecurity and employee engagement. SA Journal of Industrial Psychology/SA

Tydskrif vir Bedryfsielkunde, 36(1), Art. \#849, 8 pages.

DOI: 10.4102/sajip.v36i1.849

\section{This article is available} at:

http://www.sajip.co.za

Note:

The material described in this article is based upon work supported by the National Research Foundation under Grant number 2053344.

(c) 2010. The Authors. Licensee: OpenJournals Publishing. This work is licensed under the Creative Commons Attribution License.

\section{ABSTRACT}

Orientation: The psychological empowerment of employees might affect their engagement. However, psychological empowerment and employee engagement might also be influenced by job insecurity.

Research purposes: The objective of this study was to examine the relationship between psychological empowerment, job insecurity and employee engagement.

Motivation for the study: Employee engagement results in positive individual and organisational outcomes and research information about the antecedents will provide valuable information for the purposes of diagnosis and intervention.

Research design, approach and method: A correlational design was used. Survey design was conducted among 442 employees in a government and a manufacturing organisation. The measuring instruments included the Psychological Empowerment Questionnaire, the Job Insecurity Inventory, and the Utrecht Work Engagement Scale.

Main findings: Statistically significant relationships were found between psychological empowerment, job insecurity and employee engagement. A multivariate analysis of variance showed that affective job insecurity had a main effect on three dimensions of psychological empowerment (viz. competence, meaning and impact) and on employee engagement. Affective job insecurity moderated the effect of psychological empowerment on employee engagement.

Practical implications: The implication of the results is that interventions that focus on the psychological empowerment of employees (viz. meaningfulness, competence, self-determination and impact) will contribute to the engagement (vigour, dedication and absorption) of employees. If job insecurity is high, it is crucial to attend to the psychological empowerment of employees.

Contribution: This study contributes to knowledge about the conditions that precede employee engagement, and shows that the dimensions of psychological empowerment (namely experienced meaningfulness, competence, impact and self-determination) play an important role in this regard.

\section{INTRODUCTION}

Tremendous pressure is put on organisations to improve their performance and increase their competitiveness in the continuously changing world of work (Ndlovu \& Parumasur, 2005). The changing world of work is characterised by life-long learning, risk taking, speed and change, networking and measuring outputs (Wentzel \& Geldenhuis, 2005). Employee engagement (May, Gilson \& Harter, 2004) and psychological empowerment (Spreitzer, 1995) are important concepts to consider when dealing with changes at work and improving performance. Psychological empowerment increases employees' sense of personal control and motivates them to engage in work, which in turn results in positive managerial and organisational outcomes (Quinn \& Spreitzer, 1997).

Conger and Kanungo (1988) describe empowerment as a process whereby conditions that foster powerlessness are identified and removed by providing efficacy information, thereby enhancing an employee's self-efficacy. According to Spreitzer (1995), psychological empowerment refers to an individual's experience of intrinsic motivation that is based on cognitions about himself or herself in relation to his or her work role. These cognitions are related to the psychological states identified by Hackman and Oldham (1980) and Kahn (1990) that impact on the intrinsic motivation of employees. Greco, Laschinger and Wong (2006) state that it is reasonable to expect that, if employees experience an empowering workplace that fosters a fit between their expectations and their working conditions, they would be more engaged in their work. Engaged employees have a sense of energetic and effective connection with their work activities and see themselves as able to deal completely with the demands of their jobs (Schaufeli, Salanova, Gonzáles-Romá \& Bakker, 2002).

As organisations focus on competition and profit margins, workers are confronted with threats of real or anticipated job loss, causing many to feel insecure about their jobs and their future work life (Holm \& Hovland, 1999). The research of Sparks, Faragher and Cooper (2001) suggests that perceptions of job insecurity correlate negatively with employee well-being. Since job insecurity is experienced as a threat and implies uncertainty, it has been described as a stressor, which is often associated with powerlessness (De Witte, 1999; De Cuyper \& De Witte, 2005; Näswall, Sverke \& Hellgren, 2005). Employee perceptions of job insecurity may cause organisations to suffer financially due to the associated costs of absenteeism and lowered employee well-being (Sparks et al., 2001). Other organisational concerns caused by perceived job insecurity include the increased turnover of employees, a decrease in worker productivity, and lower levels of commitment, employee engagement, satisfaction, loyalty, and trust in employers (De Cuyper, Bernhard-Oettel, Berntson, De Witte \& Alarco, 2008; Greenhalgh \& Rosenblatt, 1984; Holm \& Hovland, 1999; Smithson \& Lewis, 2000). 
According to Kahn (1990, p. 700), employee engagement entails 'the simultaneous employment and expression of a person's preferred self in task behaviours that promote connections to work and others, personal presence (physical, cognitive, and emotional), and active full role performances'. Specific psychological conditions contribute to engagement (Kahn, 1990). Kahn (1990) distinguished three such psychological conditions - namely, psychological meaningfulness, psychological safety and psychological availability. Two studies have been found that reported on the relationship between psychological conditions and employee engagement - namely, the study by May et al (2004) and that by Olivier and Rothmann (2007). The study by May et al. (2004) confirmed that psychological meaningfulness, psychological safety and psychological availability predict employee engagement. In a South African study, Olivier and Rothmann (2007) confirmed that two psychological conditions - namely, psychological meaningfulness and psychological availability - predict employee engagement.

Empowerment exists because of the personal convictions that employees have about their roles in the organisation (Knol \& Van Linge, 2009). From a psychological empowerment perspective, Spreitzer (1995) refers to four personal psychological determinants that might affect organisational behaviour namely, meaning, competence, self-determination and impact. These four determinants can also be regarded as psychological conditions that lead to employee engagement. The experience of being empowered has been proposed to be a mediator between empowering managerial practices and the outcomes expected from empowered workers, such as engagement, organisational commitment and job performance (Spreitzer, 1995; Stander \& Rothmann, 2008). However, no studies have been found that focus on the relationship between psychological empowerment and employee engagement. Furthermore, although research findings show that job insecurity leads to low work engagement (DeCuyper et al., 2008), little is known regarding the relationship between job insecurity and psychological empowerment.

The above discussion suggests that a need exists to investigate the relationship between psychological empowerment and employee engagement in South African organisations. Furthermore, it is necessary to assess whether job insecurity affects psychological empowerment and employee engagement. The objective of this study was to investigate the relationship between psychological empowerment, job insecurity, and employee engagement.

\section{Psychological empowerment and employee engagement}

According to Spreitzer (1995), psychological empowerment exists when employees perceive that they exercise some control over their work lives. Psychological empowerment is not a fixed personality attribute. It consists of cognitions that are shaped by the work environment. Various schools of thought regarding psychological empowerment have evolved over time, including in the work of Conger and Kanungo (1988), Thomas and Velthouse (1990) and Spreitzer (1995)

According to Conger and Kanungo (1988, p. 474), empowerment refers to a

'process of enhancing feelings of self-efficacy among organizational members through the identification of conditions that foster powerlessness and through their removal by both formal organizational practices and informal techniques of providing efficacy information'

(Conger et al., 1988)

Thomas and Velthouse (1990) extended Conger and Kanungo's (1988) model and identified four dimensions of task cognitions that affect intrinsic task motivation - namely, choice (i.e. the degree to which individuals perceive that they have choice in initiating and regulating actions, [also called selfdetermination]), meaningfulness (i.e. the perceived value of the task or goal), competence (i.e. self-efficacy) and impact (i.e. the degree to which behaviour accomplishes the purpose of the task).

Using the four cognitions of Thomas and Velthouse's (1990) model, Spreitzer (1995) developed and empirically validated a multidimensional measure of psychological empowerment in the workplace. Spreitzer (1995) defines empowerment as intrinsic motivation manifested in four cognitions reflecting an individual's orientation to his or her work role. The four cognitions are meaning, competence, self-determination and impact. Meaning refers to a sense of purpose or personal connection to work (Mishra \& Spreitzer, 1998). Empowered people feel that their work is important to them and they care about what they are doing (Quinn \& Spreitzer, 1997). Competence reflects individuals' beliefs that they have the necessary skills and abilities to perform their work well (Mishra \& Spreitzer, 1998). Self-determination refers to a sense of freedom about how individuals do their work (Mishra \& Spreitzer, 1998). Impact describes a belief that individuals can influence the system in which they are embedded (Mishra \& Spreitzer, 1998). Quinn and Spreitzer (1997) state that impact is the accomplishment one feels in achieving goals. Employees fear and tend to avoid situations that they believe exceed their skills, whereas they get involved in activities and behave confidently when they judge themselves capable of handling situations that would otherwise be intimidating (Mishra \& Spreitzer, 1998). The four dimensions of empowerment could help people to feel more in control (Spreitzer, 1995).

Macey and Schneider (2008) distinguish between three broad conceptualisations of employee engagement - namely, state, trait and behavioural engagement. State engagement, which is relevant for the purposes of this study, can be seen as an extension of the self to a role (Kahn, 1990). According to Kahn (1990, p. 694), engagement refers to the harnessing of organization members' selves to their work roles'. Employee engagement consists of three dimensions - namely, vigour, dedication and absorption (Schaufeli et al., 2002). Vigour is characterised by high energy levels and mental resilience when working, the willingness to invest effort in one's work, not easily becoming fatigued, and persistence even in the face of difficulties. Dedication refers to strong involvement in one's work, characterised by enthusiasm and pride in one's job, and feeling inspired and challenged by it. Absorption is characterised by concentrating fully on one's work. It refers to a pleasant state in which one is totally immersed in one's work forgetting about everything else.

Kahn (1990) and May et al. (2004) note that, in order for the human spirit to thrive at work, individuals must be able to engage themselves cognitively, emotionally and physically. The three dimensions of employee engagement that were distinguished by Schaufeli et al. (2002) overlap conceptually with the three dimensions of engagement according to Kahn (1990), namely a physical dimension (vigour), a cognitive dimension (absorption), and an emotional dimension (dedication).

Spreitzer (1995) found that satisfaction, managerial effectiveness, innovative behaviour, and decreased stress were moderately related to empowerment. Given that empowered employees believe in themselves and the work that they do, they are more engaged. Studies by May et al. (2004) and Olivier and Rothmann (2007) found that three psychological conditions contribute to individuals engaging in their work roles - namely, psychological meaningfulness, psychological safety and psychological availability. The current study focuses on the four dimensions of psychological empowerment (meaning, competence, self-determination and impact) as possible conditions that will contribute to individuals' engaging themselves in their work roles. Based on the definitions of the four dimensions by Mishra and Spreitzer (1998), employees could ask themselves four questions when engaging in role behaviour: 
- How meaningful is it for me to adopt this behaviour?

- How competent am I to do so?

- How autonomous am I to do so?

- How strong is my impact when I bring myself into this behaviour?

\section{Meaningfulness}

Applied to the work context, meaningfulness is defined as 'the value of a work goal or purpose, judged in relation to an individual's own id' (May et al., 2004, p. 14). Meaningfulness results from the feeling that job tasks are valuable and make a difference. People are self-expressive and creative and therefore they will seek out work roles that allow them to behave in ways that express their self-concepts. Work roles and activities that are aligned with individuals' self-concepts should be associated with more meaningful work experiences. Empowered employees derive a greater sense of meaning from their work (Avolio, Zhu, Koh \& Bhatia, 2004). The restoration of meaning in work is seen as a method to foster an employee's motivation and attachment to work, thus resulting in engagement (May et al., 2004; Nelson \& Simmons, 2003; Olivier \& Rothmann, 2007).

\section{Competence}

According to Ryan and Deci (2001), research has shown that feeling competent and confident with respect to valued goals is associated with enhanced intrinsic motivation and well-being. Engaged employees see themselves as able to deal completely with the demands of their jobs (self-efficacy) (Llorens, Salonova, Bakker \& Schaufeli, 2007). Maslach, Schaufeli and Leiter (2001) found a strong correlation between self-efficacy and engagement.

\section{Self-determination}

Self-endorsed goals will enhance employee engagement, while heteronomous goals, even when introduced efficaciously, will not (Ryan \& Deci, 2001). Goals that are selected through selfdetermination are well-internalised and autonomous (Ryan, Huta \& Deci, 2008). According to Ryan et al. (2008), one cannot be following one's true self and not be autonomous.

\section{Impact}

Impact implies organisational involvement and reflects whether individuals feel that they are making a difference in their organisation (Spreitzer et al., 1997). Impact implies a sense of progression towards a goal and individuals' belief that their actions are making a difference in their organisations, which contributes to employee engagement.

The following hypothesis is formulated based on the abovementioned discussion:

Hypothesis 1: Psychological empowerment (meaning, competence, self-determination and impact) predicts employee engagement.

\section{Job insecurity}

Job insecurity relates to people in their work context who fear that they may lose their jobs and become unemployed (De Witte, 1997, 1999). Probst (2002) defines job security as the perceived stability and continuance of one's job. According to the definition proposed by Greenhalgh and Rosenblatt (1984, p. 438 ), job insecurity refers to 'powerlessness to maintain desired continuity in a threatened job situation'.

Job insecurity is usually conceptualised as either a global or a multidimensional concept (De Witte, 1999). According to the global point of view, job insecurity is defined as the threat of job loss or job uncertainty (De Witte, 1999; Mauno \& Kinnunen, 2002). According to De Witte (2000), job insecurity consists of two dimensions, namely a cognitive and an affective dimension. Cognitive job insecurity relates to perceptions of possible job loss, whereas affective job insecurity relates to the fear of job loss. Job insecurity is one of the most distressful aspects of the work situation (De Witte, 1999). It is related to mental health complaints, lower levels of job satisfaction, lower levels of job involvement, decreased trust and engagement and increased intention to leave (De Cuyper \& De Witte, 2005; Näswall et al., 2005). Greenhalgh and Rosenblatt (1984) emphasise that the sense of powerlessness experienced by employees intensifies the experienced threat of job insecurity.

Researchers agree that perceived powerlessness (lack of psychological empowerment) is undoubtedly an important variable in the study of job insecurity (Greenhalgh \& Rosenblatt, 1984; Probst, 2003). According to De Cuyper and De Witte (2005), job insecurity induces strain for the worker involved. In response to this, Greasley, Bryman, Price, Soetanto and King (2005) found that workers who consider themselves empowered have reduced levels of emotional strain. This finding is supported by Cho, Laschinger and Wong (2006), who reported that empowerment had a direct positive effect on the areas of work life, which in turn negatively affected emotional exhaustion. Disempowered individuals have to put in specific efforts, energy and time to adapt to the pressures of job insecurity. It is clear that this energy cannot then be used for working towards achieving organisational goals (De Cuyper \& De Witte, 2005).

De Cuyper et al. (2008) found job insecurity to be a statistically significant factor that was negatively related to employee engagement $(r=-0.18)$. The researchers also suggested that job insecurity might lead to feelings of uncontrollability and unpredictability. Therefore, employees' psychological empowerment is influenced by how secure they feel about their work roles. Individuals will feel empowered when they feel secure about themselves. Insecurity might distract employees from feeling empowered. This might result in lower employee engagement.

The following hypothesis is formulated based on the abovementioned discussion:

Hypothesis 2: Job insecurity affects the psychological empowerment (meaning, competence, self-determination and impact) and engagement of employees.

TABLE 1

Characteristics of the participants

\begin{tabular}{|c|c|c|c|}
\hline Item & Category & Frequency & $\%$ \\
\hline \multirow[t]{4}{*}{ Age } & 35 years and younger & 196 & 44 \\
\hline & $36-45$ years & 121 & 27 \\
\hline & 46 years and older & 95 & 22 \\
\hline & Missing & 30 & 7 \\
\hline \multirow[t]{3}{*}{ Gender } & Male & 272 & 62 \\
\hline & Female & 162 & 37 \\
\hline & Missing & 8 & 1 \\
\hline \multirow[t]{4}{*}{ Race } & Black & 227 & 52 \\
\hline & White & 160 & 36 \\
\hline & Others & 35 & 8 \\
\hline & Missing & 20 & 4 \\
\hline \multirow[t]{4}{*}{ Qualification } & Up to grade 12 & 311 & 70 \\
\hline & Diploma and degree & 100 & 23 \\
\hline & Postgraduate qualification & 30 & 7 \\
\hline & Missing & 1 & - \\
\hline \multirow[t]{4}{*}{ Years of service } & Less than 5 years & 138 & 31 \\
\hline & $6-10$ years & 96 & 22 \\
\hline & More than 10 years & 199 & 45 \\
\hline & Missing & 9 & 2 \\
\hline \multirow[t]{2}{*}{ Industry } & Manufacturing & 164 & 37 \\
\hline & Government & 278 & 63 \\
\hline
\end{tabular}




\section{RESEARCH DESIGN}

\section{Research approach}

A survey design was used (Huysamen, 2001). This design is suitable to study the relationships between different variables. Questionnaires were used to gather primary data in a nonrandom field survey.

\section{Research method}

\section{Participants}

A convenience sample consisting of employees from a government and a manufacturing organisation was used in this study. The population included workers from all levels, ranging from semi-skilled to professionals. The lowest-level employees had a literacy level adequate to allow for the valid completion of the questionnaires. The biographical characteristics of the study population are detailed in Table 1.

Table 1 indicates that $52 \%$ of the study population was black. Sixty-two percent of the participants in this study were men. The largest group of participants in terms of age (44\%) fell in the ' 35 years and younger' group and $70 \%$ had grade 12 as their highest level of education. Slightly more than half of the study population (i.e. 53\%) had been employed by the organisation for less than ten years.

\section{Measuring instruments}

Three standardised questionnaires were used in the empirical study - namely, the Psychological Empowerment Questionnaire (Spreitzer, 1995), the Job Insecurity Inventory (De Witte, 2000) and the Utrecht Work Engagement Scale (Schaufeli et al., 2002). Biographical information was also gathered regarding the participants' race, gender, age, qualifications and tenure.

The Psychological Empowerment Questionnaire (PEQ) (Spreitzer, 1995) was used in this study. The scale contains three items for each of the four sub-dimensions of psychological empowerment (for example, meaning: 'The work I do is meaningful to $\mathrm{me}^{\prime}$; competence: 'I have mastered the skills necessary for my job'; self-determination: 'I have significant autonomy in determining how to do my job'; and impact: 'I have a great deal of control over what happens in my department') The respondents indicated the extent to which they agreed with each statement on a seven-point scale, ranging from 1 (strongly disagree) to 7 (strongly agree). A higher score means a higher degree of psychological empowerment. Using structural equation modelling, Stander and Rothmann (2009) have confirmed the construct validity of the PEQ. They found that a four-factor structure (including meaning, competence, self-determination, and impact) fitted the data best. Cronbach's alpha coefficients of the PEQ varied from 0.81 (competence) to 0.89 (meaning).

The Job Insecurity Inventory (JII) (De Witte, 2000) was developed primarily to measure employees' feelings about job insecurity. It consists of 11 items that summarise both the cognitive and affective dimensions of job insecurity and are arranged along a five-point scale, ranging from 1 (strongly disagree) to 5 (strongly agree). An example of a statement relating to cognitive job insecurity would be, 'I think that I will be able to continue working here', whereas an example of a statement relating to affective job insecurity would be, 'I am worried about keeping my job'. De Witte (2000) reported that the items of the questionnaire measuring total insecurity displayed a Cronbach's alpha coefficient of 0.92 , with both scales having high reliability. The six items measuring cognitive job insecurity displayed a Cronbach's alpha coefficient of 0.90 and the five items of affective job insecurity had a Cronbach's alpha coefficient of 0.85 (De Witte, 2000). A simple principle components analysis was conducted on the 11 items of the JII of the total sample of employees. An analysis of eigenvalues (larger than one) and scree plot indicated that two factors could be extracted, explaining $51 \%$ of the variance. Two items were problematic. Items 10 and 11 both loaded on the affective subscales instead of the cognitive scale. These two items were removed from the analyses.

The Utrecht Work Engagement Scale (UWES) (Schaufeli et al., 2002) was used to measure employee engagement. The UWES makes use of a seven-point frequency scale ranging from 0 (never) to 6 (always). The UWES has three scales, namely vigour (six items), dedication (five items), and absorption (six items). Examples of items relating to the three dimensions are the following: 'I am bursting with energy in my job' (vigour); 'I find my work full of meaning and purpose' (dedication); and 'When I am working, I forget everything around me' (absorption). A simple principal component analysis was conducted on the 17 items of the UWES of the total sample of employees. The analysis of eigenvalues (larger than one) and scree plot indicated that only one factor could be extracted, explaining $52 \%$ of the total variance. This result supports the finding of Storm and Rothmann (2003) that a one-factor model fitted the data best in a sample of police members in South Africa.

\section{Research procedure}

The management of the organisations were approached to obtain permission to conduct the study among employees. The participants gave informed consent to indicate their willingness to participate in the study by signing a return slip. All ethical guidelines applicable to the treatment of human subjects in research were observed in all the steps of the study. Fieldworkers administered the questionnaires on the participants in the different organisations. The questionnaires were collected directly after they had been completed by the participants. The participants completed the questionnaires anonymously. The fieldworkers explained to the participants that the questionnaires would be treated confidentially.

\section{Statistical analysis}

The analysis was carried out with the SPSS 15.0 program (SPSS 2006) and the Amos program (Arbuckle, 2006). Descriptive statistics (e.g. means and standard deviations), alpha coefficients, correlations and multivariate analysis of variance (MANOVA) were used to analyse the data. Cronbach's alpha coefficients $(\alpha)$ were used to assess the internal consistency of the measuring instruments (Clark \& Watson, 1995). Pearson product-moment correlation coefficients were used to specify the relationships between variables. The level of statistical significance was set at $p<0.01$. A cut-off point of 0.30 (medium effect, Cohen, 1988; Steyn, 2002) was set for the practical significance of the correlation coefficients.

Structural equation modelling, as implemented in AMOS (Arbuckle, 2006), was used to test structural models by using maximum likelihood analyses. The following indexes produced by AMOS were used in this study: the chi-square statistic, which is the test of absolute fit of the model, the Goodness-of-Fit Index (GFI), the Adjusted Goodness-of-Fit Index (AGFI), the Normed Fit Index (NFI), the Comparative Fit Index (CFI), the Tucker-Lewis Index (TLI) and the Root Mean Square Error of Approximation (RMSEA). The invariance of the structural models of the PEQ was tested using the likelihood ratio test (LRT; Vandenberg \& Lance, 2000). The LRT assesses the difference in chi-square (i.e. $\Delta \chi^{2}$ ) per degree of freedom between the initially developed model and a more restricted model, including equality constraints. Using the LRT, a nonsignificant $\Delta \chi^{2}$ indicates that the parameters constrained to equality are not significantly different across groups.

The significance of differences in psychological empowerment and employee engagement scores between low and high job insecurity groups was established by means of MANOVA. Structural equation modelling (SEM) methods were used as implemented by AMOS (Arbuckle, 2006). In the first 
TABLE 2

Descriptive statistics, alpha coefficients and Pearson correlations of the measuring instruments

\begin{tabular}{|c|c|c|c|c|c|c|c|c|c|c|}
\hline \multicolumn{2}{|c|}{ Scale } & \multirow{2}{*}{$\begin{array}{r}\text { Mean } \\
16.75\end{array}$} & \multirow{2}{*}{$\frac{S D}{3.96}$} & \multirow{2}{*}{$\begin{array}{c}\alpha \\
0.74\end{array}$} & \multirow{2}{*}{1} & \multirow{2}{*}{$\frac{2}{-}$} & \multirow{2}{*}{3} & \multirow{2}{*}{4} & \multirow{2}{*}{5} & \multirow{2}{*}{$\begin{array}{l}6 \\
-\end{array}$} \\
\hline 1. & Competence & & & & & & & & & \\
\hline 2. & Meaning & 16.10 & 4.06 & 0.83 & $0.76^{*+\dagger}$ & - & - & - & - & - \\
\hline 3. & Impact & 13.35 & 4.45 & 0.77 & $0.34^{*+}$ & $0.41^{*}+$ & - & - & - & - \\
\hline 4. & Self-determination & 14.77 & 4.14 & 0.76 & $0.51^{*+t}$ & $0.55^{*+t}$ & $0.55^{\star}+$ & - & - & - \\
\hline 5 . & Cognitive job insecurity & 9.44 & 3.14 & 0.73 & -0.08 & $-0.14^{*}$ & $-0.11^{*}$ & $-0.13^{*}$ & - & - \\
\hline 6 . & Affective job insecurity & 19.01 & 6.13 & 0.83 & -0.09 & $-0.10^{*}$ & $-0.19^{*}$ & -0.06 & -0.07 & - \\
\hline 7. & Employee engagement & 69.68 & 22.42 & 0.94 & $0.33^{*}+$ & $0.48^{* \dagger}$ & $0.30^{*}+$ & $0.27^{*}$ & -0.07 & $-0.24^{*}$ \\
\hline
\end{tabular}

* Statistically significant $p<0.01 ; \uparrow$ Correlation is practically significant $r>0.30$ (medium effect); $\dagger \dagger$ Correlation is practically significant $r>0.50$ (large effect)

TABLE 3

Manova of psychological empowerment and employee engagement as dependent variables, and cognitive and affective job insecurity as independent variables

\begin{tabular}{lccccc}
\hline Variable & Value & $\boldsymbol{F}$ & $\boldsymbol{d f}$ & Error $\boldsymbol{d f}$ & $\boldsymbol{p}$ \\
\hline Cognitive job insecurity & 0.99 & 0.89 & 5 & 448 & \\
Affective job insecurity & 0.94 & 5.61 & 5 & 448 & 0.45 \\
\hline * Statistically significant difference: $p<0.01$ & & &
\end{tabular}

* Statistically significant difference: $p<0.01$

step, a multi-group structural model was constructed that distinguished between individuals scoring high and low on both cognitive and affective job insecurity. In the second step, the structural paths between psychological empowerment and employee engagement were constrained equally across groups. The $\chi^{2}$ statistic and degrees of freedom provide the basis for comparison with the initial multi-group model, in which no equality constraints were imposed.

\section{RESULTS}

\section{Descriptive statistics, alpha coefficients, and correlations}

Descriptive statistics, Cronbach's alpha coefficients and Pearson correlations of the PEQ, JII and UWES for employees working in the selected organisations are reported in Table 2.

The information reflected in Table 2 indicates that acceptable Cronbach's alpha coefficients were obtained on all the scales (Bless \& Higson-Smith, 1995). It can be concluded that the results obtained from the measuring instruments are reliable.

Table 2 shows that cognitivejob insecurity correlates statistically negatively with meaning, self-determination and impact. Affective job insecurity correlates statistically negatively with impact. Affective job insecurity correlates statistically negatively with employee engagement. The sub-scales of psychological empowerment were statistically significantly related to employee engagement. Meaning showed the highest correlation with employee engagement $(r=0.48$; practically significant, medium effect). Competence and impact were also practically significantly related to employee engagement (both medium effects). No practically significant correlation was obtained between any of the job insecurity sub-scales and employee engagement.

\section{Main and interaction effects}

Next, the main and interaction effects of cognitive and affective job insecurity on psychological empowerment and employee engagement were tested. In order to prepare the data for the analyses of main and interaction effects, the cognitive and affective job insecurity groups were both divided into two groups, consisting of scores lower than the 50th percentile and scores higher than the 50th percentile.

As indicated by Table 3, there was a significant effect of affective job insecurity on the combined dependent variables psychological empowerment and employee engagement $\left(F_{(5.448)}\right.$ $=5.61, p<0.01$; Wilk's Lambda $=0.94$; partial $\left.\eta^{2}=0.06\right)$. This effect was small ( $6 \%$ of the variance explained). An analysis of each individual dependent variable (not reported in Table 3) showed that the groups differed in terms of the level of competence $\left(F_{(1.452)}=7.47, p<0.01\right.$, partial $\left.\eta^{2}=0.02\right)$, meaning $\left(F_{(1,}\right.$ ${ }_{454)}=10.14, p<0.01$, partial $\left.\eta^{2}=0.02\right)$, impact $\left(F_{(1,454)}=5.34, p<0.01\right.$, partial $\left.\eta^{2}=0.01\right)$, and employee engagement $\left(F_{(1.454)}=25.95, p<\right.$ 0.01 , partial $\eta^{2}=0.05$ ). Individuals who scored high on affective job insecurity (compared to those with low scores) experienced significantly less competence, meaning, impact, and employee engagement. Therefore, a small main effect of affective job insecurity on three dimensions of psychological empowerment and employee engagement was confirmed.

Next, the hypothesised structural model (unconstrained) for low and high negative affectivity groups was tested using structural equation modelling as implemented by AMOS (Arbuckle, 2006). According to Byrne (2001), the primary focus of the estimation process in SEM is to yield parameter values such that the residual between the sample covariance matrix and population covariance matrix implied by the model is minimal.

One of the two dimensions (namely psychological empowerment) was covered by at least two scales. For this dimension, a latent variable was specified on which the corresponding scales loaded, separating random measurement error from true score variance. For employee engagement there was only one indicator, meaning that in these cases there was a one-to-one correspondence between the manifested variables (scales) and the underlying latent dimensions. Usually no distinction is made in these cases between random error variance and true score variance, so that the correlations among these one-indicator latent variables and other latent variables may be biased (Little, Cunningham, Shahar \& Widaman, 2002). This problem was overcome by means of a procedure proposed by Bagozzi and Heatherton (1994). First, a one-factor model was fitted for all items belonging to the scale. Second, separate indicators for the scale were formed by selecting items on the basis of their loadings, alternating items with high and low loadings. Thus, two parcels of items were created for employee engagement.

Figure 1 shows the structural model for the low and high job insecurity groups.

Upon inspecting the path coefficients from the observed variables to psychological empowerment, it is evident that individuals categorised as falling within the high and low affective job insecurity group experienced psychological empowerment differently. Table 4 shows that the standardised regression coefficients of meaning, competence, impact and self-determination were different for the high and low affective job insecurity groups. Therefore, it is possible that the structure 


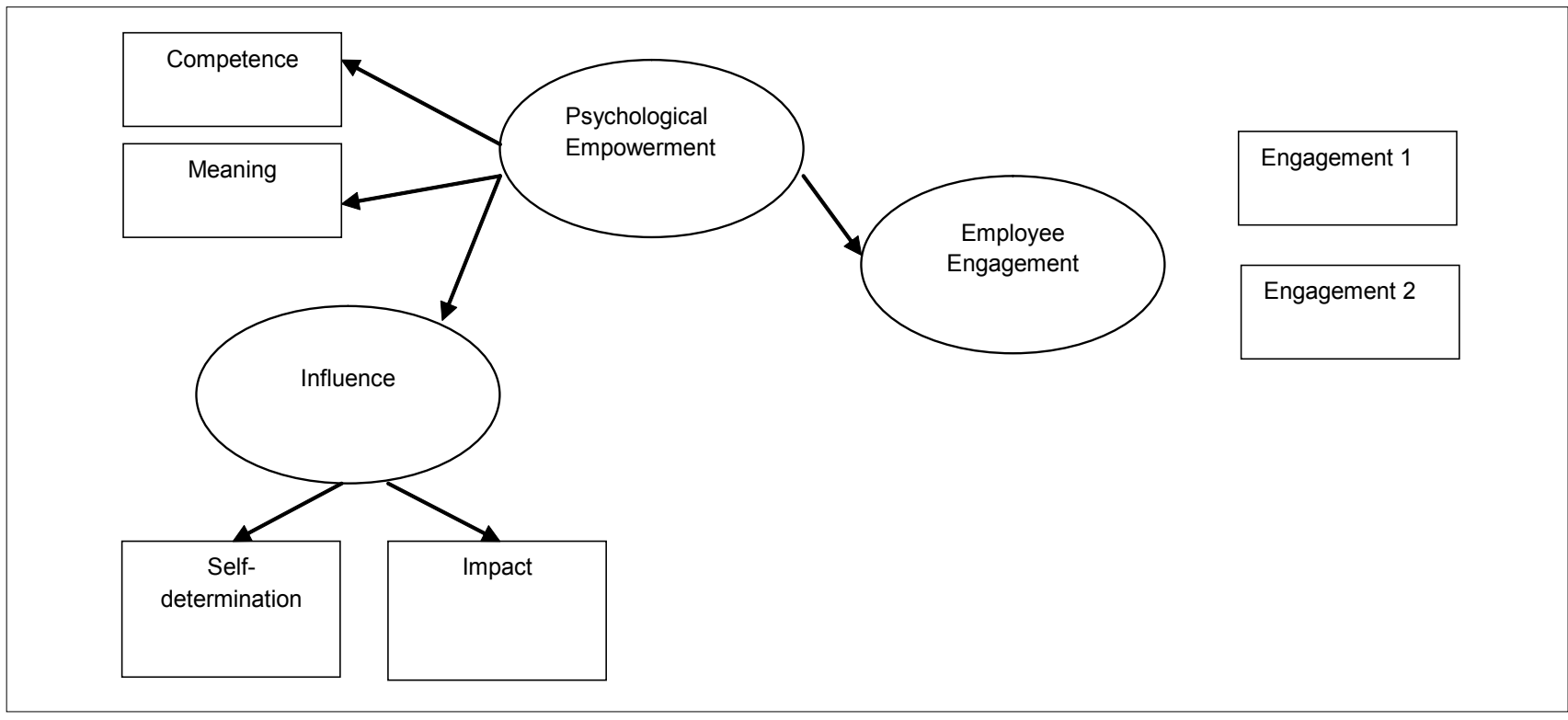

FIGURE 1

Structural model of employee engagement

TABLE 4

Standardised regression coefficients for low and high affective job insecurity groups

\begin{tabular}{|c|c|c|c|c|c|c|c|c|c|}
\hline \multicolumn{5}{|c|}{ Low Affective Job Insecurity } & \multicolumn{5}{|c|}{ High Affective Job Insecurity } \\
\hline \multicolumn{3}{|l|}{ Scale } & \multicolumn{2}{|l|}{$\beta$} & \multicolumn{3}{|c|}{ Scale } & & $\beta$ \\
\hline \multicolumn{3}{|c|}{ Influence-Psychological empowerment } & \multicolumn{2}{|l|}{0.85} & \multicolumn{3}{|c|}{ Influence-Psychological empowerment } & & 0.55 \\
\hline \multicolumn{3}{|c|}{ Engagement-Psychological empowerment } & \multicolumn{2}{|l|}{0.31} & \multicolumn{3}{|c|}{ Engagement-Psychological empowerment } & & 0.65 \\
\hline \multicolumn{3}{|c|}{ Competence-Psychological empowerment } & \multicolumn{2}{|l|}{0.90} & \multicolumn{4}{|c|}{ Competence-Psychological empowerment } & 0.72 \\
\hline Impact-Influence & & & \multicolumn{2}{|l|}{0.66} & \multicolumn{4}{|c|}{ Impact-Influence } & 0.59 \\
\hline Self-determination-Influ & & & \multicolumn{2}{|l|}{0.81} & \multicolumn{4}{|c|}{ Self-determination-Influence } & 0.94 \\
\hline Meaning-Psychological & & & \multicolumn{2}{|l|}{0.90} & \multicolumn{4}{|c|}{ Meaning-Psychological empowerment } & 0.98 \\
\hline Engagement 1-Employe & ment & & \multicolumn{2}{|l|}{0.99} & \multicolumn{4}{|c|}{ Engagement 1-Employee engagement } & 0.91 \\
\hline Engagement 2-Employe & ment & & \multicolumn{2}{|l|}{0.90} & \multicolumn{4}{|c|}{ Engagement 2-Employee engagement } & 0.89 \\
\hline \multicolumn{10}{|c|}{$\begin{array}{c}\text { TABLE } 5 \\
\text { Goodness-of-fit statistics for the unconstrained model }\end{array}$} \\
\hline Model & $x^{2}$ & $d f$ & $x^{2} / d f$ & GFI & AGFI & NFI & TLI & CFI & RMSEA \\
\hline Affective job insecurity & 30.65 & 14 & 2.19 & 0.98 & 0.93 & 0.98 & 0.98 & 0.99 & 0.05 \\
\hline
\end{tabular}

of psychological empowerment differs for groups measuring low and high on affective job insecurity.

In the unconstrained model (see Figure 1), psychological empowerment predicted $9.6 \%$ of the variance in employee engagement in the low affective job insecurity group. In the high affective job insecurity group, psychological empowerment predicted $42.4 \%$ of the variance in employee engagement $\left(\chi^{2}=203.97, d f=16, p<0.01\right)$. The fit statistics for the unconstrained model are shown in Table 5.

Table 4 shows that the standardised regression coefficients of psychological empowerment on employee engagement were different in the low and high affective job insecurity groups. In the unconstrained model, psychological empowerment predicted $40 \%$ of the variance in employee engagement in the high affective job insecurity group. In the low affective job insecurity group, psychological empowerment predicted $9.6 \%$ of the variance in employee engagement $\left(\chi^{2}=30.65, d f=14, p<0.01\right)$. Hypothesis 1 is accepted. It seems that psychological empowerment predicts employee engagement.

To test for possible interaction effects between affective job insecurity and psychological empowerment, the path from psychological empowerment to employee engagement was constrained equally for the low and high affective job insecurity groups. The constrained model was statistically significantly different from the unconstrained model $\left(\Delta \chi^{2}=14.79 ; \Delta d f=1 ; p<0.01\right)$.). This result suggests that affective job insecurity interacted with psychological empowerment in affecting employee engagement. Hypothesis 2 is therefore accepted.

\section{DISCUSSION}

The objective of this study was to examine the relationship between psychological empowerment, job insecurity and employee engagement. Psychological empowerment (consisting of competence, meaning, impact and self-determination) predicted employee engagement in a statistically significantly way. The results showed that affective job insecurity had a main effect on three dimensions of psychological empowerment (viz. competence, meaning and impact) and employee engagement. Psychological empowerment interacted with affective job insecurity to affect employee engagement.

The Pearson correlations showed that three dimensions of psychological empowerment - namely, meaning, competence and impact, were practically significantly related to employee engagement, while self-determination was statistically significantly related to employee engagement. Therefore, individuals who experience a sense of purpose in their work, 
who believe they have the skills and abilities to do their work, who believe that they can influence the system in which they are embedded, and who have self-endorsed goals (Mishra \& Spreitzer, 1998; Quinn \& Spreitzer, 1997) are more engaged in their work.

The correlations between the dimensions of psychological empowerment and job insecurity were not practically significant. Furthermore, none of the dimensions of job insecurity were practically significantly related to employee engagement. Affective job insecurity predicted $5.76 \%$ of the variance in employee engagement. Multivariate analysis of variance showed that affective job insecurity had a statistically significant negative effect on psychological empowerment and employee engagement. This effect was small $(6 \%$ of the variance explained). More specifically, affective job insecurity had a small effect on competence, meaning, impact and employee engagement. These findings confirm the findings of De Cuyper et al. (2008) that job insecurity impacts negatively on the engagement of employees.

Employees who fear that they will lose their jobs might experience a loss of meaning (i.e. their experiences of a sense of purpose are affected), competence (i.e. their belief that they have the skills and abilities to do their work is affected), and impact (i.e. their belief that they can influence the system in which they are embedded is affected). Greasley et al. (2005) found that workers who perceive themselves as empowered experience reduced levels of job insecurity (emotional strain). The loss of meaning, competence and impact might have resulted in lower levels of engagement.

The structural model confirmed that psychological empowerment (consisting of meaning, competence, impact and self-determination) predicted employee engagement. The standardised regression coefficients showed that meaning, competence and influence (consisting of impact and selfdetermination) were predictors of employee engagement in both high and low affective insecurity groups. However, the effect of psychological empowerment on employee engagement was stronger when affective job insecurity was high (40\% of the variance explained) compared to when affective job insecurity was low (10\% of the variance explained). It can thus be concluded that affective job insecurity moderated the effect of psychological empowerment on employee engagement.

Under conditions of high affective job insecurity, meaning, competence and influence (i.e. impact and self-determination) contributed strongly to employee engagement. It seems that the experience of meaningful work contributes to the engagement of employees when they fear that they might lose their jobs. Previous studies showed that, when opportunities are created to experience meaning in work, employees' attachment to work is stimulated, thus resulting in engagement (May et al., 2004; Nelson \& Simmons, 2003; Olivier \& Rothmann, 2007). Feeling competent at work also contributes to engagement when employees fear that they might lose their jobs. According to selfdetermination theory (Ryan \& Deci, 2001), feeling competent and confident with respect to valued goals is associated with enhanced intrinsic motivation. Influence (including selfdetermination and impact) also has a strong effect on the engagement of employees when they fear that they might lose their jobs. Self-determined goals are well-internalised and autonomous (Ryan et al., 2008). Impact reflects whether individuals feel as though they are making a difference in their organisation (Spreitzer et al., 1997). This study showed that psychological empowerment contributes strongly to employee engagement, especially under conditions of high job insecurity. In the current business environment it is crucial that managers empower their people. It is recommended that organisations implement interventions to increase the psychological empowerment of employees. Supervisors and managers play an important role in creating engaging work environments (Greco et al., 2006). Interventions should focus on meaningful work, competence, self-determination and impact. Supervisors and managers must create work environments in which people experience their work as meaningful and where they feel that they can influence events (May et al., 2004). They should also build the competence of the employees. Furthermore, they could create autonomy-supportive work climates by taking employees' perspectives into account, providing greater choice, and encouraging self-initiation (Gagne \& Deci, 2005). Influence (self-determination and impact) is stimulated when managers and supervisors provide a meaningful rationale for performing an uninteresting task, acknowledge the perspective and feelings of employees about tasks, and structure work to allow interdependence among employees.

This study had various limitations. First, a cross-sectional design was used and therefore it was not possible to control for confounding variables. It was not possible to establish the causality of relationships. Future studies should employ longitudinal designs to study the relationships between psychological empowerment, job insecurity and employee engagement. Second, at least one item of one of the scales of the PEQ (i.e. meaning) shows overlap with one item of the UWES. This could have inflated the relationship between meaning and employee engagement. Third, self-reports were used, which limit the responses of the participants to the items used in the scale and do not capture the richness and variety of the responses that are possible.

Future studies should focus on the relationship between psychological empowerment, job insecurity and employee engagement in a longitudinal design. Such studies should investigate the effects of psychological empowerment and employee engagement on staff turnover, absenteeism, performance and safety.

\section{REFERENCES}

Arbuckle, J.L. (2006). Amos user's guide version 7.0. Chicago: Amos Development Corporation.

Avolio, B.J.,Zhu, W., Koh, W., \& Bhatia, P. (2004). Transformational leadership and organizational commitment: Mediating role of psychological empowerment and moderating role of structural distance. Journal of Organizational Behavior, 25, 951-968.

Bagozzi, R.P., \& Heatherton, T.F. (1994). A general approach to representing multifaceted personality constructs: Application to state self-esteem. Structural Equation Modeling, 1, 35-67.

Bless, C., \& Higson-Smith, C. (1995). Fundamentals of social research methods: An African perspective. (2nd edn.). Cape Town: Juta.

Byrne, B.M. (2001). Structural equation modelling with AMOS: Basic concepts, applications, and programming. Mahwahn: Lawrence Erlbaum.

Cho, J., Laschinger, H.K.S., \& Wong, C. (2006). Workplace empowerment, work engagement and organizational commitment of new graduate nurses. Canadian Journal of Nursing Leadership, 19(3), 43-60.

Clark, L.A., \& Watson, D. (1995). Construct validity: Basic issues in objective scale development. Psychological Assessment, 7, 309-319.

Cohen, J. (1988). Statistical power analysis for the behavioral sciences . (2nd edn.). Hillsdale: Lawrence Erlbaum.

Conger, J.A., \& Kanungo, R.N. (1988). The empowerment process: Integrating theory and practice. Academy of Management Review, 13, 471-482.

De Cuyper, N., \& De Witte, H. (2005). Job insecurity: mediator or moderator of the relationship between type of contract and various outcomes. South African Journal of Industrial Psychology, 31(4), 79-86.

De Cuyper, N., Bernhard-Oettel, C., Berntson, E., De Witte, H., \& Alarco, B. (2008). Employability and employees' wellbeing: Mediation by job insecurity. Applied Psychology: An International Journal, 57, 488-509. 
De Witte, H. (1997, April). Long term job insecurity as a stressor: Its impact on satisfaction and commitment. Paper presented at the 8th European Congress on Work and Organizational Psychology, Verona, Italy.

De Witte, H. (1999). Job insecurity and psychological well-being: Review of the literature and exploration of some unresolved issues. European Journal of Work and Organizational Psychology, $8,155-177$.

De Witte, H. (2000). Arbeidethos en jobonzekerheid: Meting en gevolgen voor welzijn, tevredenheid en inzet op het werk. [Labour ethics and job insecurity: Measurement and consequences for well-being, satisfaction and labour input]. In R. Bouwen, K. de Witte, H. de Witte \& T. Taillieu (Eds.), Van groep tot gemeenschap. Liber Amicorum Prof. Dr L. Lagrou. Leuven: Garant.

Gagne, M., \& Deci, E.L. (2005). Self-determination theory and work motivation. Journal of Organizational Behavior, 31, 331-362.

Greasley, K., Bryman, A., Price, A., Soetanto, R., \& King, N. (2005). Employee perceptions of empowerment. Employee Relations, 27, 354-368.

Greco, P., Laschinger, H.K., \& Wong, C. (2006). Leader empowering behaviours,staffnurseempowermentandworkengagement/ burnout. Nursing Research, 19(4), 41-56.

Greenhalgh, L., \& Rosenblatt, Z. (1984). Job insecurity: Toward conceptual clarity. Academy of Management Review, 9, 438-448.

Hackman, J.R., \& Oldham, G.R. (1980). Work redesign. Reading: Addison-Wesley.

Holm, S., \& Hovland, J. (1999). Waiting for the other shoe to drop: Help for the job-insecure employee. Journal of Employment Counseling, 36(4), 156-166.

Huysamen, G.K. (2001). Methodology for the social and behavioural sciences. CapeTown:Oxford UniversityPress.

Kahn, W.A. (1990). Psychological conditions of personal engagement and disengagement at work. Academy of Management Journal, 33, 692-724.

Knol, J., \& Van Linge, R. (2009). Innovative behaviour: The effect of structural and psychological empowerment on nurses. Journal of Advanced Nursing, 65, 359-370,

Little, T.D., Cunningham, W.A., Shahar, G., \& Widaman, K.F. (2002). To parcel or not to parcel: Exploring the question, weighing the merits. Structural Equation Modeling, 9, 151-173.

Llorens, S., Salanova, M., Bakker, A., \& Schaufeli, W.B. (2007) Does a positive gain spiral of resources, efficacy beliefs and engagement exist? Computers in Human Behavior, 23, 825-841.

Macey, W.H., \& Schneider, B. (2008). The meaning of employee engagement. Industrial and Organizational Psychology, 1, 3-30.

Maslach, C., Schaufeli, W.B., \& Leiter, M.P. (2001). Job burnout. Annual Review of Psychology, 52, 397-422.

Mauno, S., \& Kinnunen, U. (2002). Perceived job insecurity among dual-earner couples: Do its antecedents vary according to gender, economic sector and the measure used? Journal of Occupational and Organisational Psychology, $75,295-314$

May, D.R., Gilson, R.L., \& Harter, L.M. (2004). The psychological conditions of meaningfulness, safety and availability and the engagement of the human spirit at work. Journal of Occupational and Organizational Psychology, 77, 11-37.

Mishra, A.K., \& Spreitzer, G.M. (1998). Explaining how survivors respond to downsizing: The roles of trust, empowerment, justice, and work redesign. Academy of Management Review, $22,567-588$.

Näswall, K., Sverke, M., \& Hellgren, J. (2005). The moderating role of personality characteristics on the relationship between job insecurity and strain. Work $\mathcal{E}$ Stress, 19, 37-49.

Ndlovu, N., \& Parumasur, S.B. (2005, March). The perceived impact of downsizing and organisational transformation on survivors. Paper presented at the Changing World of Work Conference, Vanderbijlpark, South Africa.
Nelson, D.L., \& Simmons, B.L. (2003). Health psychology and work stress: A more positive approach. In J.C. Quick \& L.E. Tetrick (Eds.), Handbook of occupational health psychology (pp. 97-119). Washington: American Psychological Association.

Olivier, A.L., \& Rothmann, S. (2007). Antecedents of work engagement in a multinational oil company. SA Journal of Industrial Psychology, 33(3), 49-56.

Probst, T.M. (2002). The impact of job insecurity on employee work attitudes, job adaptation, and organizational withdrawal behaviors. In J.M. Brett \& F. Drasgow (Eds.), The psychology of work: Theoretically based empirical research (pp. 141-168). Mahwah: Lawrence Erlbaum.

Probst, T.M. (2003). Development and validation of the Job Security Index and the Job Security Satisfaction Scale: A classical test theory and IRT approach. Journal of Occupational and Organizational Psychology, 76, 451-467.

Quinn, R.E., \& Spreitzer, G.M. (1997). The road to empowerment: Seven questions every leader should consider. Organizational Dynamics, 26(2), 37-48.

Ryan, R.M., \& Deci, E.L. (2001). On happiness and human potentials: A review of research on hedonic and eudaimonic well-being. Annual Review of Psychology, 52, 141-166.

Ryan, R.M., Huta, V., \& Deci, E.L. (2008). Living well: A selfdetermination theory perspective on eudaimonia. Journal of Happiness Studies, 9, 139-170.

Schaufeli, W.B., Salanova, M., Gonzáles-Romá, V., \& Bakker, A.B. (2002). The measurement of engagement and burnout: A confirmatory factor analytic approach. Journal of Happiness Studies, 3, 71-92.

Smithson, J., \& Lewis, S. (2000). Is job insecurity changing the psychological contract? Personnel Review, 29, 680-702.

Sparks, K., Faragher, B., \& Cooper, C.L. (2001). Well-being and occupational health in the 21st century workplace. Journal of Occupational and Organisational Psychology, 74, 489-509.

Spreitzer, G.M. (1995). Psychological empowerment in the workplace: Dimensions, measurement and validation. Academy of Management Journal, 38, 1442-1465.

Spreitzer, G.M., Kizilos, M.A., \& Nason, S.W. (1997). A dimensional analysis of the relationship between psychological empowerment, and effectiveness, satisfaction, and strain. Journal of Management, 23, 670-704.

SPSS 15.0 for Windows. [Computer software] (2006). Chicago: SPSS Inc.

Stander, M.W., \& Rothmann, S. (2008). Leadership, job satisfaction and organisational commitment. South African Journal of Human Resource Management, 6(3), 7-13.

Stander, M.W., \& Rothmann, S. (2009). Psychological empowerment of employees in selected organisations In South Africa. South African Journal of Industrial Psychology, 35, 196-203.

Steyn, H.S. (2002). Practically significant relationships between two variables. South African Journal of Industrial Psychology, $28,10-15$.

Storm, K., \& Rothmann, S. (2003). The validation of the Utrech Work Engagement Scale in the South African Police Services. South African Journal of Industrial Psychology, 29(4), 62-70.

Thomas, K.W., \& Velthouse, B.A. (1990). Cognitive elements of empowerment: An 'interpretive' model of intrinsic task motivation. Academy of Management Review, 15, 666-681.

Vandenberg, R.J., \& Lance, C.E. (2000). A review and synthesis of the measurement invariance literature: Suggestions, practices, and recommendations for organizational research. Organizational Research Methods, 3, 4-69.

Wentzel, A., \& Geldenhuis, P. (2005, March). The dynamics of incongruence in the changing world of work. Paper presented at the Changing World of Work Conference, Vanderbijlpark, South Africa. 